\title{
Pensertipikatan Tanah Desa Adat di Bali Melalui Program Percepatan Pendaftaran Tanah Sistematis Lengkap
}

\author{
Veronika Puteri Kangagung1, Wayan P. Windia ${ }^{2}$
}

${ }^{1}$ Fakultas Hukum Universitas Udayana, E-mail: veronivue@gmail.com 2Fakultas Hukum Universitas Udayana, E-mail: windiapendet@yahoo.com

\begin{tabular}{l}
\hline Info Artikel \\
\hline Masuk: 19 Februari2021 \\
Diterima:4 Juni 2021 \\
Terbit: 1 Juli 2021 \\
Keywords: \\
Land Registration Process; \\
Desa Adat; The Complete \\
Systematic Land Acceleration \\
Program (PTSL) \\
\\
\\
\\
Corresponding Author: \\
Veronika Puteri Kangagung, \\
E-mail: \\
windiapendet@yahoo.com \\
DOI: \\
10.24843/AC.2021.v06.i02.p11 \\
\\
Kata kunci: \\
Proses Pensertipikatan Tanah; \\
Percepatan Prondaftaran Tanah \\
Sistematis Lengkap (PTSL) \\
\end{tabular}

\begin{abstract}
This research attempts to through the process of the custom's certificate in Bali through a registration process systematic land complete (PTSL). This research is compiled according results from normative legal analysis by a statute approach and consep tual approach to examine the concep tof the sovereignty of communal along the technique of tracing legal materials uses document studies and uses qualitative descriptive analysis. Conclusion these articles first of all, the existence from traditional village land in Bali is quite strong because it is recognized based on positive law as well recognized in Balinese customary lawaccording awig-awig. The second is the procedure for certifying traditional village land in Bali which is carried out through the PTSL program can be said to be simpler than the procedure for certifying gunakaya land (privately owned land). This simpler procedure has in several ways brought unfavorable consequences for landowners and the community in general, such as: (1) There are claims from residents or PTSL applicants on customary land parcels which are then upgraded to property rights in their names instead of names local adat village. (2) There's transfer rights like buying and selling or auction because the Right Dependents (HT) is placed on a customary land parcel but it has been certified in the name of a private person, not a customary village.
\end{abstract}

\footnotetext{
Abstrak

Penelitian ini bertujuan untuk menjelaskan proses pensertipikatan tanahadatdi Bali melewati proses Pendaftaran Tanah Sistematis Lengkap (PTSL). Penelitian disusun berdasarkan hasilanalisishukum normatif bersama pendekatan peraturan perundang undangan serta pendekatan konsep guna mengkaji konsep dari hak pemilikan komunal serta teknik penelusuran bahan hukum menggunakan studi dokumen dan memakai analisis yang deskriptif kualitatif. Kesimpulan artikel ini, pertama, eksistensi tanah desa adat di Balicukup kuat karena diakui berdasarkan hukum positif juga diakui berdasarkan hukum positifjugadiakui dalam hukum adat Bali sesuai awigawig desa setempat. Kedua, tata cara pensertipikatan tanah Desa adat di Bali yang dilakukan melalui program PTSL dapat dikatakan lebih sederhana dibandingkan dengan tata cara
} 
pensertipikatan tanah gunakaya (tanah milik perseorangan). Tata cara yang lebih sederhana ini, dalam beberapa hal membawa konsekuensi yang belum sesuai untuk pemilik tanah dan masyarakat contohnya (1) Adanya klaim dari warga atau pemohon PTSL atas bidang tanah adat yang kemudian ditingkatkan haknya menjadi hak milik atas namanya bukan nama desa adat setempat. (2) Adanya peralihan hak seperti jual beli atau lelang karena dipasang Hak Tanggungan (HT) atas bidang tanah adat namun telah disertipikatkan atas nama pribadi bukan desa adat.

\section{Pendahuluan}

Pemerintah melakukan Pendaftaran Tanah Sistematis Lengkap (biasa disebut PTSL) untuk mempercepat pensertipikatan lahan agraria di Indonesia sebagai kelanjutan makna Pasal 19 Undang Undang Nomor 5/1960 (disingkat dengan UU PA). Tujuan dari PTSL dikerjakan baik oleh perseorangan sebagai hak gunakaya, kelompok/komunitas maupun desa adat yakni pertama agar mendapatkan keyakinan dan pengamanan tentang hukum bagi pemilik alas hak atas lahan agarianya, kelompok rumah susun hak-hak lain mana terdaftar sebagai pemilik yang berhak; Selanjutnya, untuk mempermudah akses tersedianya informasi mengenai bahan fisik juga bahan yuridis mana dibutuhkan oleh masyarakat dan pemerintah terhadap lahan serta satuan rumah susun atau rusun; dan ketiga, untuk mentertibkan administrasi pertanahan agar sesuai dengan aturan dalam pendaftaran atas tanah. Kepastian akan alas hak desa adat sehingga memberikan jaminan akan kepastian hukum yang sepanjang ini masih membingungkan apabila disandingkan dengan jenis-jenis hak dalam UU PA secara yuridis terwujud dengan ditunjuknya desa adat sebagai subyek hak atas tanah, ungkap I Ketut Sudantra pada disuatu Seminar Nasional Hukum Adat yang diselenggarakan oleh Program Studi Magister Kenotariatan Fakultas Hukum Universitas Udayana di Denpasar, pada 25 Juli 2018.

Pemerintah sudah mengumumkan peraturan guna mendukung program PTSL tersebut diantaranya : (a) UU PA; (b) Peraturan Menteri Agraria Tata Ruang Nomor 12/2017 (umum disebut Kepmen ATR/BPN tentang PTSL); (c) Surat Keputusan Menteri Agraria Tata Ruang Nomor 276/KEP-19.2/X/2017, diubah atas Surat Keputusan Menteri Agraria Tata Ruang Nomor 575/SK-HR.01/X/2019 pada tanggal 17 Oktober 2019 (selanjutnya disebut Kepmen ATR/BPN 19).

Tanah pada intinya merupakan lapisan atau permukaan terluar atau kulit bumi sehingga hukum tanah yang diterapkan yakni hukum adat. Dengan demikian hukum adat diakui secara konstituonal Pasal 18B Undang Undang Dasar 1945 (bisa dinamakan UUDNRI 1945), dimana keeksistensian hukum adat secara kesatuan bersama hak tradisionalnya selama diakui, masih eksis juga dihormati oleh negara Indonesia. Dalam hubungan terkait perlindungan hak dan pengakuan atas hak bersama masyarakat hukum adat atau begitu juga dengan keberadaan desa adat di Bali, maka Pemerintah telah mengeluarkan Peraturan Daerah Nomor 4 Tahun 2019 (dikatakan sebagai Perda 2019). Desa adat sesuai Pasal 1 angka 8 Perda 2019 menegaskan yakni Kesatuan Masyarakat Hukum Adat (selanjutnya disingkat KMHA) 
dimana bertugas dan berwenang mengatur rumah tangganya dimana mereka mempunyai tata krama pergaulan masyarakat yang telah lama atau turun menurun dalam kahyangan desa berisikan daerah, derajat, kelompok murni, hak menurut adat, kapital yang mandiri, kebiasaan, adab pertalian hidup masyarakat sejak lama.

Menurut Wayan P. Windia dalam Forum Group Discussion Kementrian Agraria Tata Ruang Bali pada tanggal 30 Agustus 2017, bertempat di Gedung Nayaka Loka, Kebun Raya Bedugul, sejumlah kekayaan milik desa adat dinamakan padruwen desa adat yaitu bersifat materiil dan immaterial, meliputi: (1) Padruwen desa yang berhubungan dengan parhyangan, contohnya adalah Pura. (2) Padruwen desa yang berhubungan dengan pawongan, contohnya adalah awig-awig desa lalu pipil krama desa, dan Lembaga Perkreditan Desa (LPD). (3) Padruwen desa yang berhubungan dengan palemahan, yakni umumnya lahan kepunyaan desa (bisa dikatakan Tanah Adat), dan lingkungan alam desa adat.

Dikemukakan di atas bahwa pensertipikatan tanah penting dilakukan baik tanah perseorangan (tanah gunakaya), tanah kelompok/komunitas, maupun Tanah Desa Adat. Walaupun sudah tersedia peraturan perundang-undangan yang merupakan landasan hukum untuk memungkinkan untuk mensertipikatkan tanah desa adat, tetapi dalam kenyatannya tidak mudah mensertipikatkan tanah desa adat. Hal ini didasarkan beberapa sebab, seperti: (1) Sampai sekarang belum ada kesatuan pendapat/konsep mengenai tanah desa adat. Salah satu contoh, apakah yang dimaksud tanah desa adat terbatas hanya pada tanah pekarangan desa ataukah termasuk tanah teba (tanah tegalan/kering yang melekat pada pekarangan desa). (2) Tidak ada keseragaman ketentuan awig-awig desa adat mengenai keberadaan/eksistensi tanah desa adat di Bali. Terdapat suatu desa adat tertentu dimana masih sangat kuat mempertahankan eksistensi tanah desa adat, sementara desa adat yang lainnya, relatif lemah. Bahkan ada tanah desa adat yang telah disertipikatkan atas nama pihak krama (warga) desa adat yang menguasainya. Bersamaan dengan kenyataan tersebut Pemerintah Republik Indonesia sedang gencar melaksanakan Percepatan Pelaksanaan Pendaftaran Tanah Sistimatis Lengkap.

Penelitian ini penting karena ingin menjelaskan tentang proses pensertipikatan tanah adat di Bali melalui PTSL. Studi sebelumnya tidak mengusung objek pada tulisan ini. I Gede Angga Pratama mengkaji tindakan Pejabat Pembuat Akta Tanah kaitannya pada sistem pendaftaran lahan adat Bali. Beliau berkesimpulan bahwa tidak diperlukan peran PPAT di dalam penerbitan sertipikat PTSL karena tidak adanya perbuatan hukum. ${ }^{1}$ Untuk itu diperlukan penelitian lanjutan terkait eksistensi tanah desa adat di Bali pada dewasa ini dan bagaimana tata cara dan konsekuensi pensertipikatan tanah desa adat yang dilakukan melalui proses PTSL. Bersamaan dengan masalah yang diteliti ini, bertujuan supaya menganalisis dan mengenal tentang eksistensi tanah desa adat di Bali pada dewasa ini dan bagaimana tata cara dan konsekuensi pensertipikatan tanah desa adat yang dilakukan melalui proses PTSL.

\footnotetext{
1 Pratama, I. G. A. Peran PPAT dalam Sistem Pendaftaran Tanah Adat di Bali. Acta Comitas: Jurnal Hukum Kenotariatan, 4(2). doi: https:// doi.org/10.24843/ AC.2019.v04.i02.p11, h. 292.
} 


\section{Metode Penelitian}

Artikel disusun berdasarkan hasil analisis hukum normatif (hanya mengkaji peraturan-peraturan atau bahan-bahan tertulis yang berlaku atau mengikat) bersama pendekatan peraturan perundang undangan serta konsep (conseptual approach) guna mengkaji konsep dari hak pemilikan komunal. Beberapa bahan hukum yang dikaji, seperti: UUDNRI 1945; UU PA; Kepmen ATR/BPN tentang PTSL; Kepmen ATR/BPN 19; Perda 2019. Hasil kajiannya kemudian dianalisis untuk menemukan jawaban atas dua pokok permasalahan yang menjadi fokus perhatian dalam artikel ini, seperti dikemukakan di atas. Teknik penelusuran untuk bahan hukum memanfaatkan studi dokumen dan memakai analisis yang deskriptif berdasarkan kualitatif yang umumnya menonjolkan proses dan makna.

\section{Hasil dan Pembahasan}

\subsection{Pengakuan Tanah Desa Adat di Bali Ditinjau dari Hukum Positif}

Tanah druwe desa merupakan sebutan bagi tanah desa adat Bali di bawah kekuasaan desa adat. Desa adat merupakan istilah untuk menyebut lembaga sosial religius yang menaungi KMHA yang ada pada masing-masing desa di Bali. Ia memiliki hak otonomi yang berasal pada aturan adat guna mengurusi rumah tangganya tanpa campur tangan yang lain. Hak tersebut meliputi menciptakan hukum sendiri yang dikenal dengan sebutan awig awig, menjalankan norma bersama prajuru adat, mengadili serta membereskan secara mandiri konflik pada institusi kemudian menjalankan keamanan melalui pecalangan.

Klasifikasi tanah adat di Bali meliputi pertama, lahan druwe desa, kedua lahan laba pura, ketiga lahan pekarangan desa, dan terakhir lahan ayahan desa. Menurut ketentuannya, bentuk dan fungsi lahan adat Bali, yakni :

1. Tanah druwe desa : lahan yang dipunyai desa pakraman contohnya lahan untuk pasar, lahan untuk lapangan, dan lahan untuk kuburan.

2. Tanah laba pura: lahan yang terikat pada satu atau lebih Pura dimana bernilai hasil seperti lahan tani atau kebun yang diperuntukkan sebagai sumber hasil.

3. Tanah pekarangan desa : lahan dipunyai desa pakraman dimana diserahkan pada krama negak yakni warganya guna ruang berdiam.

4. Tanah ayahan desa : lahan dipunyai dan di kerjakan oleh desa pakraman seperti lahan tani yang hasilnya bisa disalurkan kepada warganya. ${ }^{2}$

Pengakuan terhadap lahan Adat di Bali, perlu dipahami lebih awal mengenai keberadaan Desa di Propinsi Bali, yaitu ada 2 (dua) desa, pertama adalah "Desa Adat" atau "Desa Pakraman" lalu kedua yakni "Desa" ("Desa Dinas" atau "Desa Administratif"). Keduanya mempunyai wewenang, tugas, dasar hukum, sejarah, pengertian, dan struktur, serta tata kelola organisasi, juga kekayaan yang tidak sama. Dimaksud "Desa" dalam artikel ini adalah "Desa Adat" sesuai Pasal 1 Nomor 8 Perda 2019, intinya merupakan KMHA di Bali yang bertugas dan berwenang mengatur rumah tangganya dimana mereka mempunyai tata krama pergaulan masyarakat yang telah lama atau turun menurun dalam kahyangan desa terdapat daerah, derajat,

2 Andika, I. B. N. T., Astara, I. W. W., \& Seputra, I. P. G. (2021). KedudukanHukum Tanah Adat Pelaba Pura sebagai Tanah Ulayat di Desa Tampaksiring Kabupaten Gianyar. Jurnal Konstruksi Hukum, 2(1), 133-137. doi: https://10.22225/ikh.2.1.2982.133-137, h. 135. 
kelompok murni, hak menurut adat, kapital yang mandiri, kebiasaan, adab pertalian hidup masyarakat sejak lama. Ada suatu desa adat yang berisikan satu banjar adat serta adapula berisikan lebih dari satu banjar adat. Banjar Adat sesuai dalam Pasal 1 Nomor 9 Perda 2019 yaitu banjar suka duka.

Perbedaan antara desa di Bali dengan desa serupa selain di Bali terletak pada unsur pokoknya. Sesuai Pasal 6 Perda 2019 menegaskan desa adat berunsurkan parahyangan, pawongan, serta palemahan yaitu wujud konsep Tri Hita Karana mengandung, pertama perasaan bhakti krama kepada Hyang Widhi Wasa/ Tuhan Yang Maha Esa. Kedua, kesetiakawanan/ punia atau rasa kebersamaan, kepedulian, dan antar sesama krama; dan ketiga, adanya keselarasan, keserasian, dan kewelas-asihan/asih krama kepada wilayah juga arena sekitar. Tri Hita Karana tersebut bernilaikan kebajikan Bali setempat, yakni sumber kebahagiaan dan kesejahteraan bagi kehidupan warga (Sad Kerthi), diantaranya: (a) penyucian jiwa (atma kerthi); (b) penyucian laut (segara kerthi); (c) penyucian sumber air (danu kerthi); (d) penyucian tumbuh-tumbuhan (wana kerthi); dan (e) penyucian manusia (jana kerthi); serta (f) penyucian alam semesta (jagat kerthi).

Menurut Swastawa Dharmayudha mengelompokan tanah desa adat menjadi 4 jenis yaitu: (a) Tanah desa merupakan tanah yang diperoleh desa adat secara langsung didapat bisa melalui dengan membeli. Contoh tanah tersebut yaitu tanah yang digunakan sebagai pasar dan kuburan (setra). (b) Tanah laba pura merupakan tanah kepunyaan pada waktu dulu oleh desa peruntukannya hanya bagi Pura. (3) Tanah PKD adalah tanah penguasaan yang diserahkan pada krama oleh desa adat untuk membuat rumah, lazimnya dengan ukuran rumah yang luasnya seragam bagi setiap krama. (4) Tanah AYDs yakni tanah kepemilikan desa adat yang penggunaanya diberikan pada setiap krama yang mana dapat mengambil hasil penggunaan tanah tersebut dan diwajibkan melakukan ayahan (bisa dengan tenaga atau materi). ${ }^{3}$

Pasal 55 Perda tersebut menjalankan pula padruwen (kepunyaan) desa adat. Pada pokoknya berisikan semua harta kekayaan yang sifatnya materiil (seperti wewidangan desa adat) dan immateriil (misalnya kepercayaan, nilai, dan adat yang dijiwai Agama Hindu) kepunyaan desa adat adalah padruwen desa adat. Hubungan dengan tanah desa adat yang mana merupakan satu diantara padruwen atau kepunyaan desa adat, desa adat tidak sepenuhnya menguasai. Menurut Wayan P. Windia dalam Seminar bersama I Ketut Sudantra di atas, berdasarkan kepemilikan dan/atau penguasaannya, tanah desa sebagai salah satu padruwen desa adat, sebagai berikut:

(a) Kelompok tanah desa dimana penggunaannya dimiliki penuh desa, contoh lahan : tegak pura dan laba pura.

(b) Kelompok tanah desa adat yang penggunaannya dimiliki penuh krama desa secara turun-temurun, seperti: tanah pekarangan desa (selanjutnya disingkat PKD).

(c) Kelompok tanah yang dahulu milik desa adat dan saat ini sudah milik tanah perseorangan. Tanah tersebut seperti tanah laba pura (dahulu) dan sekarang ini menjadi sertipikat atas nama pemangku pura.

(d) Kelompok tanah dahulu milik desa adat dan kini berubah kegunaan dengan tidak beralaskan hak secara jelas menjadi suatu bangunan

${ }^{3}$ Dharmayuda, I MadeSwasthawa. (2001). Desa Adat, Kesatuan Masyarakat Hukum Adat di Propinsi Bali. Denpasar: Upada Sastra, h. 136. 
pemerintah, seperti: beralih fungsi menjadi Kantor Desa/Kelurahan atau bangunan sekolah dasar yang diberikan pemanfaatannya kepada perseorangan krama desa. Adapun lahan dimaksud yakni tanah pekarangan dan ayahan desa atau biasa dikenal tanah PKD dan tanah AYDs.

Berdasarkan penjelasan di atas maka eksistensi tanah desa adat di Bali terbilang cukup kuat karena diakui berdasarkan hukum positif dinyatakan pula dalam hukum adat Bali sesuai awig-awig desa. Pengakuan terhadap eksistensi tanah desa adat di Bali berdasarkan hukum positif antara lain dapat diketahui dari: (1) Pasal 18B UUDNRI 1945; (2) Pasal 19 UU PA; (3) Kepmen ATR/BPN tentang PTSL; (4) Kepmen ATR/BPN 19; (5) Perda 2019.

Pengakuan tanah tersebut juga diakui berdasarkan Hukum Adat Bali atau lebih dikenal awig-awig desa adat. Hal ini diketahui dari Pawos 22/Pasal 22 seperti awig-awig tertulis yang tertuang dalam sistimatika awig-awig tertulis pada literatur "Pedoman/Teknis Penyusunan Awig-awig dan Keputusan Desa Adat"4 Diatur antara lain: Krama desa pengamong karang desa (tanah sane tan keni tigasana) patut ngewatesin karang inucap antuk pagehan/turus utawi tembok mangde pekantenannya asri. (Warga desa yang menguasai tanah desa adat/lahan yang pajak tidak dikenai, patut memberi batas terhadap lahannya berisi pagar agar kelihatan indah). Dengan demikian eksistensi tanah desa adat di Bali adalah cukup kuat, mengingat keberadaannya diakui berdasarkan peraturan perundang-undangan juga peraturan adat di Bali sesuai awig awig.

\subsection{Pengaturan dan Konsekuensi Pensertipikatan Tanah Desa Adat di Bali yang Dilakukan Lewat Program PTSL}

Bab Pendahuluan telah mengemukakan bahwa pensertipikatan tanah penting dilakukan oleh perseorangan sebagai hak gunakaya, hak kelompok atau hak komunitas maupun desa adat dengan beberapa tujuan yakni: (1) Adanya perlindungan serta kepastian hukum terhadap atas nama sertipikat dan/atau atas nama satuan rumah susun (rusun) dilampiri bukti bahwa atas nama itu adalah pemilik; (2) bagi pihak yang memerlukan akan diberikan pemberitahuan terkait hal itu; dan (3) terciptanya tertib administrasi pertanahan. Pensertipikatan tanah melalui program PTSL didasarkan atas payung hukum Instruksi Presiden Nomor 2 Tahun 2018 yang mana obyek PTSL mencakup seluruh kegiatan pendaftaran tanah pertama sekali secara serentak tanpa terkecuali, termasuk lahan belum beralaskan hak atau lahan tanpa batas-batasnya di semua hamparan negara pada suatu kediaman, diantaranya pelengkapan dan ditetapkannya data yuridis juga fisik dari suatu atau banyak bidang obyek. 5

Kegiatan PTSL di Bali menggunakan prinsip pada aturan dalam Pasal 4 (4) Permen ATR/BPN 6/2018 yaitu tahapnya : (a) Perencanaan; (b) Ditetapkannya Titik

\footnotetext{
${ }^{4}$ Biro Hukum dan HAMSetda Propinsi Bali. (2002). Pedoman/Teknis Penyusunan Awig-awig dan Keputusan Desa Adat. Denpasar: Biro Hukum dan HAM Setda Propinsi Bali Tahun Anggaran 2002, h. 8-48.

${ }^{5}$ Ardani, M. N. (2019). Peran Kantor Pertanahan dalam Kegiatan Pendaftaran Tanah Sistematis Lengkap. Gema Keadilan, 6(1), 45-62. doi: https://doi.org/10.14710/gk.6.1.44-62, h. 53.
} 
Koordinat; (c) Mempersiapkan segala perlengkapannya; (d) Penentuan serta Dibentuknya Dewan Ajudikasi PTSL serta Satuan Kerja; (e) Pengarahan; (f) Penghimpunan Bukti yang Berwujud dan Menurut Hukum; (g) Pengkajian Bukti Menurut Hukum dalam hal Pembuktian Hak; (g) Publikasi Bukti Fisik serta Yuridis untuk Pengesahan; (h) Penegasan Konversi, Pengakuan serta Pemberian Hak; (i) Pembukuan Hak; (j) Diterbitkannya Alas Sah Perseorangan/Lahan Adat; (k) Dokumentasi yang dilanjutkan dengan Pemberian Sertipikat; (l) Pelaporan ${ }^{6}$ yang mana disesuaikan dengan keadaan kondisi keberadaan tanah milik perseorangan dan tanah milik banjar adat ataupun tanah Pura di Bali. Secara umum hambatan dan kendala yang dilakukan pada program PTSL di Bali tentunya bagi pemohon pribadi perseorangan tidak menjadi masalah sepanjang tanah yang dimiliki pemohon mempunyai batas-batas yang jelas dan diketahui penyanding dan kepala desa. Lain halnya jika tanah tersebut milik sekelompok masyarakat hukum adat dan ada beberapa krama adat yang menempati tanah adat tersebut sehingga harus benar dipastikan batas-batasnya oleh kelian adat, bendesa adat dan kepala desa agar tidak timbul masalah dikemudian harinya. ${ }^{7}$

Pihak BPN sebagai pelaksanaan di lapangan terkait PTSL harus bisa menggandeng tokoh masyarakat di tingkat desa, bendesa adat, camat serta yang terkait dalam hal memberikan sosialisasi pemahaman mengenai prosedur dan syarat melakukan PTSL agar bisa meningkatkan perekonomian dan pinjam kredit di bank, hal ini sejalan dengan penelitian mengenai potensi permasalahan mengenai PTSL. Sedangkan untuk pensertipikatan tanah adat di Bali, pada intinya menyebutkan pengaturan pelaksanaannya sebagaimana hukum adat secara turun temurun serta masih ada hingga sekarang yang dinamis serta sesuai dengan asas penyelenggaraan pemerintah desa adat. Hal ini penting disertipikatkan agar dapat diketahui mana tanah adat yang bisa dimanfaatkan secara ekonomi untuk kepentingan adat bersama dan juga menghindari adanya tanah milik adat yang disertipikatkan secara pribadi oleh warga. ${ }^{8}$

Guna mendorong kelancaran dari pelaksanaan program PTSL di seluruh Indonesia, khususnya di Bali, pandangan Prayitno dalam suatu Seminar Nasional PTSL, yaitu pihak terkait telah melakukan terobosan dalam hal (a) adanya pihak swasta yang dilibatkan dalam hal pemetaan juga pengukuran obyek; (b) Menambah juru pengukuran di lingkungan setempat; (c) Keikutsertaan dari swasta sebagai CSR; (d) Umumnya publikasi yang semula 2 (dua) bulan ke dalam 14 (empatbelas) hari kerja; (e) Teruntuk peserta yang pendapatannya kurang maka disediakan BPHTB terhutang baginya; (f) adanya Surat keputusan Bersama (SKB) antar pejabat terkait mengenai

\footnotetext{
${ }^{6}$ Avu, I. K. (2019). Kepastian Hukum Pendaftaran Tanah Melalui Pendaftaran Tanah Sistematis Lengkap di Kota Batu. Mimbar Hukum-Fakultas Hukum Universitas Gadjah Mada, 31(3), 338-351. doi: https:/ / doi.org/10.22146/imh.41560, h. 342.

7 Rachma, Y. (2019). Pelayanan Pendaftaran Tanah Sistematis Lengkap (PTSL) oleh Kantor Pertanahan Kabupaten Pangandaran di Desa Wonoharjo Kecamatan Pangandaran Kabupaten Pangandaran. Moderat: Jurnal Ilmiah Ilmu Pemerintahan, 5(4), 519-529. doi: http://dx.doi.org/10.25157/moderat.v5i4.3064, h. 526.

8 Adnyani, N.P., Kuswahyono, I., \& Suprivadi, S. (2020). Implementasi Pendaftaran Hak Atas Tanah Komunal di Desa Adat Pakraman Bungbungan Bali. Jurnal Ilmiah Pendidikan Pancasila dan Kewarganegaraan, 5(1), 148-158. doi: 10.17977/um019v5i1p148-158, h. 157.
} 
biaya persiapan PTSL. ${ }^{9}$ Berdasarkan ketentuan dalam Permen PTSL sesuai Pasal 13 ayat (2) diatur mengenai tata caranya memperoleh sertipikat tanah.

Secara sederhana, tata cara sebagaimana dimaksud dalam paragraph sebelumnya dapat digambarkan sebagai berikut: (1) Pemegang hak memiliki alas hak dasar sebagai bukti telah menguasai fisik bidang tanah tersebut seperti asli surat tanah yang berbentuk Pipil (Bali), Petok D (Jawa), Surat Keterangan Ganti Rugi (SKGR) di Sumatera. (2) Apabila tidak memiliki dasar alas hak tersebut di atas, dapat dengan lembar asli pelunasan Pajak Bumi dan Bangunan (selanjutnya disingkat PBB) obyek tersebut; lembar asli Pembayaran pelunasan PBB atas tanah; kartu identitas atau Kartu Tanda Penduduk (selanjutnya disingkat KTP) pemohon sesuai nama yang tertera di alas hak; Kartu Keluarga pemohon. (3) Penandatangani Surat pernyataan sporadik dan pengukuran bidang tanah tersebut berikut penyanding tanah itu dan diketahui dan disaksikan oleh pejabat desa setempat, mulai dari kelian adat, kelian dinas, kepala desa dan camat. (4) Jika tanah yang dimohonkan adalah tanah warisan maka ditambahkan dengan surat silsilah ahli waris, surat pernyataan ahli waris dan surat pembagian harta warisan yang diketahui oleh pejabat berwenang dari tingkat desa sampai camat serta membayar pajak waris jika tanah yang dimohonkan itu melebihi nilainya dari batas harga yang tidak kena pajak waris. (5) Surat pernyataan risalah yuridis yang ditandatangani pemohon serta sketsa bidang tanah yang dimohonkan dan saat disidang panitia A kalau tidak ada masalah secara hukum maka risalah yuridis itu akan ditandatangani oleh team sidang panita A, yaitu kepala desa dan tim sidang dari kantor pertanahan setempat yang menyidangkan permohonan tersebut. Proses permohonan sertipikat yang dilakukan secara mandiri memakan waktu 6 (enam) bulan termasuk didalamnya 2 (dua) bulan harus berada di papan pengumuman yang gunanya adalah untuk diketahui masyarakat bahwa ada permohonan atas tanah untuk menjadi sertipikat dan jika ada kendala dari pihak pemohon atau lainnya bisa memakan waktu 1 (satu) tahun atau lebih.

Pengakuan hak dalam Peraturan Pemerintah Nomor 24/1997 (dinamakan PP Pendaftaran Tanah) menyebutkan proses pengumuman guna tanah adat dilakukan dalam 30 (tigapuluh) hari guna pendaftaran tanah sistematik serta dalam kurun waktu 60 (enampuluh) hari guna pendaftaran tanah sporadik. Akan tetapi Pasal 21 ayat (1) Kepmen ATR/BPN tentang PTSL menyatakan bahwa baik proses pemberian serta pengakuan hak yakni publisitas dilaksanakan melalui lembaga pengumuman selama 14 (empatbelas) hari kalender dikarenakan aturan Permen Agraria 6/2018. Akta peralihan tidak dibutuhkan dalam hal pengumuman tentang kepunyaan tanah saat PTSL tersebut, selanjutya diganti menjadi surat pernyataan pengakuan tanah. ${ }^{10}$

Perbedaannya pensertipikatan tanah melalui program PTSL dengan program yang umum yaitu pada jangka waktu yang singkat yakni 14 (empatbelas) hari telah terbit

\footnotetext{
${ }^{9}$ Muiiburohman, D. A. (2018). Potensi Permasalahan Pendaftaran Tanah Sistematik Lengkap (PTSL). BHUMI: Jurnal Agraria dan Pertanahan, 4(1), 88-101. doi: $\underline{\mathrm{dx} . d o i . o r g / 10.31292 / j b . v 4 i 1.217}$, h. 92.

${ }^{10}$ Kusumawati, A. H., Rohmah, M., \& Sofyan, R. A. (2020). INOVASI PELAYANAN DINAS BADAN PERTANAHAN NASIONAL DALAM PENDATAAN PERTANAHAN DI KOTA BATU. Prosiding Simposium Nasional "Tantangan Penyelenggaraan Pemerintahan di Era Revolusi Indusri 4. O" , 334-356. doi: https://doi.org/10.22219/PSNIP.Vol0.No0.II/334-356, h. 348.
} 
sertipikat dan proses kelengkapan berkasnya juga sedikit, hanya memerlukan pernyataan sporadik atas tanah tersebut yang diketahui aparat desa setempat. Apabila terdapat pihak yang keberatan atas pengumuman sesuai Pasal 21, bisa diajukannya kesulitannya pada ketua panitia ajudikasi PTSL tidak lebih dari 14 (empatbelas) hari kalender dihitung dari dipublikasikannya data fisik dan yuridisnya. Perbedaan ini muncul sejalan dengan tujuan pendaftaran bidang tanah melalui program PTSL supaya terdaftar yang mana selanjutnya tahun 2025 diharapkan di Indonesia semua bidang tanah telah bersertipikat dan terdaftar.

Perlu dikemukakan PTSL diprogramkan oleh pemerintah untuk memenuhi tujuan yang berintikan bahwa supaya terhadap hak atas tanah masyarakat Indonesia bisa diberikan kepastian dan perlindungan hukum sehingga berjalan secara sederhana dan merata serta mensejahterakan perekonomian sehingga bisa meminimalisir konflik perselisihan. Terciptanya suatu bentuk desa yang lengkap untuk modal dalam membuat administrasi data base yang benar dan dapat dipercaya pada hakikatnya adalah tujuan PTSL untuk BPN.11 Tujuan PTSL dapat diketahui dari/tercantum dalam Pasal 2 ayat (2) Permen PTSL.

Berdasarkan ketentuan Pasal 4 Permen PTSL, maka dapat dikemukakan bahwa tata pensertipikatan tanah melalui program PTSL relatif lebih sederhana dibandingkan dengan pensertipikatan tanah pada umumnya. Tata caranya secara sederhana dapat digambarkan sebagai berikut. (1) Diawali dengan kegiatan keikutsertaan pemohon dalam acara penyuluhan yang diadakan oleh BPN di wilayah desa setempat. (2) Dilanjutkan dengan kegiatan pendataan terhadap para pemohon yang dilakukan oleh petugas dari Kantor BPN Kabupaten/Kota. Dalam kegiatan ini antara lain diteliti mengenai silsilah atau riwayat kepemilikan tanah yang bersangkutan, yang meliputi asal-usul kepemilikan (melalui warisan atau hibah atau jual beli, tentang pajak tanah, dll). (3) Selanjutnya petugas BPN akan mengukur dan meneliti batas-batas wilayah tanah tersebut ditemani pemohon dan pihak penyanding (pemilik tanah yang berbatasan). Pada tahap akan diakhiri dengan permintaan persetujuan penyanding.

Langkah selanjutnya berupa penelitian bahan hukum yuridis dan melakukan pemeriksaan lapangan oleh petugas BPN setempat. Sesudah keseeluruhan rangkaian kegiatan dilalui, dilanjutkan dengan pengumuman selama 14 (empatbelas) hari ke depan disertai surat persetujuan pensertipikatan tanah dengan jalan menempelkan di papan bertempat pada kantor desa setempat dan BPN Kabupaten/Kota yang bersangkutan. Setelah tahap pengumuman terlewati, dilanjutkan dengan tahap penerbitan sertipikat. Terakhir pihak pemohon akan menerima sertipikat atas nama yang bersangkutan yang akan diserahkan oleh Petugas BPN. Rangkaian kegiatan seperti ini dilakukan dalam hubungan dengan pelaksanaan program PTSL untuk jenis tanah gunakaya (tanah perseorangan) dan tidak termasuk program PTSL untuk tanah Desa Adat di Bali.

\footnotetext{
11 Istiqamah, I. (2018). Tinjauan Hukum Legalisasi Aset Melalui Pendaftaran Tanah Sistematis Lengkap (PTSL) Terhadap Kepemilikan Tanah. Jurisprudentie: Jurusan Ilmu Hukum Fakultas Syariah dan Hukum, 5(1), 226-235. doi: https://doi.org/10.24252/jurisprudentie.v5i2.5814, h. 230.
} 
Sementara tata cara pensertipikatan tanah Desa Adat di Bali melalui program PTSL agak berbeda dibandingkan dengan tata cara pensertipikatan tanah gunakaya (tanah perseorangan). Berdasarkan ketentuan Pasal 3 ayat (4) Permen PTSL, secara sederhana tata cara pensertipikatan tanah Desa Adat di Bali melalui program PTSL dapat digambarkan sebagai berikut. Diawali dengan kegiatan perencanaan dan persiapan mana dikerjakan Pejabat yang Berwenang dan bersinergi dengan BPN setempat untuk menjalankan program PTSL dan perekruitan petugas dan Upah Minimum Kabupaten (UMK). Dilanjutkan dengan penetapan lokasi ini dilakukan sebelum Panitia PTSL terbentuk. Akan dikeluarkan Surat Keputusan (selanjutnya disingkat SK) BPN Kabupaten/Kota setempat mengenai Penetapan Lokasi (Penlok) PTSL yang berisi waktu dan lokasi obyek.

Tahap berikutnya melakukan pembuatan Panitia Ajudikasi PTSL. Tahap ini dilakukan berdasarkan SK yang ditetapkan yang mana berisi susunan panitia ajudikasi PTSL berikut tugas-tugasnya, seperti:

1. Penyuluhan. Kegiatan ini bertempat di Desa/Kelurahan yang menjadi obyek. Dengan dihadiri oleh Tim BPN, para prajuru adat setempat, Peserta dan instansi seperti Kantor Polisi Resor (Kapolres) atau Kantor Polisi Sektor (Kapolsek) setempat. Tahap ini para peserta akan disosialisasikan mengenai program PTSL. Tim BPN akan memberikan arahan kepada peserta yang akan mensertipikatkan tanahnya dengan dibebankan biaya: fotokopi pipil, fotokopi KTP Pemohon, fotokopi Surat bukti Pemberitahuan Pajak Terhitung (SPPT) atau bukti PBB, fotokopi Kartu Keluarga (KK) yang bersangkutan, tidak lupa dilengkapi dengan materai 6000+3000 atau 10000, dan patok.

2. Penyatuan Data Fisik dan Yuridis Obyek. Tahap ini berisikan dikumpulkannya data secara fisik dan yuridis tanah. Data terkait obyek yang didaftarkan oleh Pemohon pada tahap ini akan dikumpulkan, dikelola data fisik dan yuridisnya.

3. Pemeriksaan Tanah. Tahapan ini akan dilakukan oleh Panitian Ajudikasi yang bertujuan menyelaraskan data Pemohon dalam Pipil dengan fisik di lapangan.

4. Data Fisik serta Yuridis Bidang Tanah Diumumkan dan Dibuktikannya Alas Hak. Jalan ini dilaksanakan manakala data fisik serta yuridis ditemukan juga dibenarkan oleh penglihatan di lapangan dimana BPN akan mendapat sket bidang yang termuat dalam Nomor Induk/ Identifikasi Bidang (NIB). Hal tersebut memuat : Nama; Luas Obyek; Batas utara timur selatan dan barat dari tanah yang kemudian ditempel pada Papan di Kantor Desa dan Kantor BPN setempat. Dalam jangka waktu 14 (empatbelas) hari apabila ada yang menyanggah atau mengajukan keberatan dapat datang ke Kantor BPN setempat dilengkapi dengan bukti-bukti atas keberatannya sebelum jangka waktu tersebut.

5. SK Atas Diberikan atau Diakuinya Alas Hak Diterbitkan. Selama 14 (empatbelas) hari apabila tidak ada bantahan ataupun masalahan terhadap pengumuman tersebut di atas maka BPN berhak menerbitkan SK Pemberian HAT. Pemohon wajib melengkapi pajak atau kewajiban penjual dan pembeli yang sudah dilunasi. Namun karena para krama adat menempati tanah desa adat sebagai tempat tinggal dan selama turun menurun tidak ada memperjualbelikan dengan orang lain maka bebas BPHTB.

6. Pembukuan dan Peneribitan Sertipikat Hak Milik (selanjutnya disingkat SHM) Desa Adat. Obyek tanah adat yang telah selesai akan dibuatkan berita acara 
penyelesaian proses PTSL yang selanjutnya akan Panitia PTSL tanda tangani sesuai dari Pejabat yang Berwenang setempat.

7. Penyerahan SHM Desa Adat. Ini adalah tahap terakhir dari proses PTSL. Penyerahan tersebut umumnya dilakukan di kediaman desa adat (bisa di balai banjar) dengan dihadiri oleh para prajuru adat. Perlu diperhatikan bahwa SHM Desa Adat ini tidak diijinkan menjadi suatu jaminan di bank dan warga tidak diperkenankan menyimpan, melainkan disimpan oleh Kepala Desa setempat. Apabila warga memerlukan maka dapat diminta di Kantor Desa.

Pensertipikatan tanah dengan program PTSL yang telah berlangsung sebagaimana pengaturannya berlangsung tidak selalu mulus. Putusan Mahkamah Agung Nomor 2272 K/Pdt/ 2019 tanggal 3 September 2019 sampai pada tingkat kasasi sebagai contoh permasalahan terkait program PTSL. Tergugat melakukan perbuatan melawan hukum yaitu mengajukan permohonan bukan sertipikat haknya. Terlepas pada pembahasan sebelumnya, perlu mendapat perhatian bahwa ada beberapa kendala yang cukup sering dijumpai pada saat PTSL diantaranya keacuhan masyarakat dan kurangnya pemahaman akan pentingnya pensertipikatan alas hak. ${ }^{12}$

Panitia di sini akan kewalahan karena peserta dalam mengikuti kegiatan memiliki minat yang rendah sehingga menjadi tanggung jawab Panitia dalam mensosialisasi dan mengedukasi agar memunculkan keinginan serta dampak yang baik untuk peserta atau masyarakat. Di samping persoalan tersebut, beberapa obyek PTSL ada yang tanahnya bersengketa yaitu berkaitan dengan sengketa hak ataupun tentang batas-batasnya. Ketidakmampuan peserta dalam memenuhi syarat administratif kerap juga menjadi bentuk hambatan di lapangan saat Panitia mengumpulkan data-data menurut A. Taufan Yogiarto. Pemahaman yang diberikan diantaranya pendaftaran secara sistematis, karena selain menghasilkan sertipikat, tetapi juga dengan ikut mengamalkan amanat UU PA berbarengan dengan pembenahan administrasi pertanahan apabila ada yang keliru dahulunya selanjutnya mengurangi persoalan berkaitan dengan tanah. ${ }^{13}$

Pensertipikatan tanah desa adat di Bali yang dilakukan melalui program PTSL dapat dikatakan lebih sederhana dibandingkan dengan tata cara pensertipikatan tanah gunakaya (tanah milik perseorangan). Menurut analisis Penulis, pengaturan pensertipikatan tanah adat membawa konsekuensi masalah dalam masyarakat setempat. Hal ini sejalan dengan pendapat Wayan P. Windia seperti dikemukakan pada Forum Group Discussion Kementrian Agraria Tata Ruang Bali. Contohnya pertama, yaitu adanya klaim dari warga/pemohon PTSL atas bidang tanah adat yang kemudian ditingkatkan haknya menjadi hak milik atas namanya bukan nama desa adat setempat. Kedua, terdapat peralihan hak seperti jual beli atau lelang karena dipasang Hak Tanggungan (HT) atas bidang tanah adat namun telah disertipikatkan atas nama pribadi bukan desa adat.

12 Ardani, M. N. (2019). Tantangan Pelaksanaan Kegiatan Pendaftaran Tanah Sistematis Lengkap dalam Rangka Mewujudkan Pemberian Kepastian hukum. Gema Keadilan, 6(3), 268286. doi: https://doi.org/10.14710/gk.6.3.268-286, h. 285.

13 Marryanti, S., \& Purbawa, Y. (2018). Optimalisasi Faktor-faktor vang Mempengaruhi Keberhasilan Pendaftaran TanahSistematis Lengkap. Bhumi: Jurnal Agraria dan Pertanahan, 4(2), 190-207. doi: https://doi.org/10.31292/ib.v4i2.278, h. 202. 


\section{Kesimpulan}

Pengakuan tanah desa adat di Bali cukup kuat karena diakui berdasarkan hukum positif juga diakui dalam hukum adat Bali sesuai awig-awig desa setempat. Pengakuan terhadap eksistensi tanah desa adat di Bali berdasarkan hukum positif antara lain dapat diketahui dari: (a) Pasal 18 B UUDNRI 1945; (b)Pasal 19 UU PA; (c) Kepmen ATR/BPN tentang PTSL; (d) Kepmen ATR/BPN 19; dan (e) Perda 2019. Pengaturan pensertipikatan lahan desa adat di Bali yang dilakukan melalui program PTSL dapat dikatakan lebih sederhana dibandingkan dengan tata cara pensertipikatan tanah gunakaya (tanah milik perseorangan). Tata cara yang lebih sederhana ini, dalam beberapa hal membawa konsekuensi yang belum sesuai untuk pemilik tanah dan masyarakat contohnya (1) Adanya klaim dari warga/pemohon PTSL atas bidang tanah adat yang kemudian ditingkatkan haknya menjadi hak milik atas namanya bukan nama desa adat setempat. (2) Adanya peralihan hak seperti jual beli atau lelang karena dipasang Hak Tanggungan (HT) atas bidang tanah adat namun telah disertipikatkan atas nama pribadi bukan desa adat. Dikemukakan dalam kesimpulan 2 (dua) hal yang berpotensi sebagai konsekuensi yang belum sesuai untuk pemilik tanah dan masyarakat, untuk mengindari konsekuensi seperti digambarkan di atas, disarankan kepada semua pihak atau instansi yang terlibat langsung dalam melaksanakan program PTSL terhadap tanah desa adat di Bali agar mengupayakan adanya sinkronisasi peraturan mengenai obyek pendaftaran tanah desa adat di Bali. Tujuannya antara lain: (a) Menghindari adanya tumpang tindih antara peraturan seperti tentang Tanah Pelaba Pura sesuai Surat Keputusan Dirjen Nomor 556/DjA/1986. (b) Menyesuaikan implementasi program PTSL dengan ketentuan awig-awig desa dan hukum adat di Bali.

\section{Daftar Pustaka / Daftar Referensi \\ Buku}

Biro Hukum dan HAM Setda Propinsi Bali. (2002). Pedoman/Teknis Penyusunan Awig-awig dan Keputusan Desa Adat. Denpasar: Biro Hukum dan HAM Setda Propinsi Bali Tahun Anggaran 2002.

Dharmayuda, I Made Swathawa. (2001). Desa Adat, Kesatuan Masyarakat Hukum Adat di Propinsi Bali. Denpasar: Upada Sastra.

\section{Jurnal}

Adnyani, N. P., Kuswahyono, I., \& Supriyadi, S. (2020). Implementasi Pendaftaran Hak Atas Tanah Komunal di Desa Adat Pakraman Bungbungan Bali. Jurnal Ilmiah Pendidikan Pancasila dan Kewarganegaraan, 5(1), 148-158. doi: 10.17977/um019v5i1p148-158.

Andika, I. B. N. T., Astara, I. W. W., \& Seputra, I. P. G. (2021). Kedudukan Hukum Tanah Adat Pelaba Pura sebagai Tanah Ulayat di Desa Tampaksiring Kabupaten Gianyar. Jurnal Konstruksi Hukum, 2(1), 133-137. doi: https://10.22225/ikh.2.1.2982.133-137.

Ardani, M. N. (2019). Peran Kantor Pertanahan dalam Kegiatan Pendaftaran Tanah Sistematis Lengkap. Gema Keadilan, 6(1), 45-62. doi: https://doi.org/10.14710/gk.6.1.44-62. 
Ardani, M. N. (2019). Tantangan Pelaksanaan Kegiatan Pendaftaran Tanah Sistematis Lengkap dalam Rangka Mewujudkan Pemberian Kepastian Hukum. Gema Keadilan, 6(3), 268-286. doi: https://doi.org/10.14710/gk.6.3.268-286.

Ayu, I. K. (2019). Kepastian Hukum Pendaftaran Tanah Melalui Pendaftaran Tanah Sistematis Lengkap di Kota Batu. Mimbar Hukum-Fakultas Hukum Universitas Gadjah Mada, 31(3), 338-351. doi: https://doi.org/10.22146/imh.41560.

Istiqamah, I. (2018). Tinjauan Hukum Legalisasi Aset Melalui Pendaftaran Tanah Sistematis Lengkap (PTSL) Terhadap Kepemilikan Tanah. Jurisprudentie: Jurusan Ilmu Hukum Fakultas Syariah dan Hukum, 5(1), 226-235. doi: https://doi.org/10.24252/jurisprudentie.v5i2.5814.

Kusumawati, A. H., Rohmah, M., \& Sofyan, R. A. (2020). INOVASI PELAYANAN DINAS BADAN PERTANAHAN NASIONAL DALAM PENDATAAN PERTANAHAN DI KOTA BATU. Prosiding Simposium Nasional'Tantangan Penyelenggaraan Pemerintahan di Era Revolusi Indusri 4. O", 334-356. doi: https://doi.org/10.22219/PSNIP.Vol0.No0.II |334-356.

Marryanti, S., \& Purbawa, Y. (2018). Optimalisasi Faktor-faktor yang Mempengaruhi Keberhasilan Pendaftaran Tanah Sistematis Lengkap. Bhumi: Jurnal Agraria dan Pertanahan, 4(2), 190-207. doi: https://doi.org/10.31292/ib.v4i2.278.

Mujiburohman, D. A. (2018). Potensi Permasalahan Pendaftaran Tanah Sistematik Lengkap (PTSL). BHUMI: Jurnal Agraria dan Pertanahan, 4(1), 88-101. doi: dx.doi.org/10.31292/ib.v4i1.217.

Pratama, I. G. A. Peran PPAT dalam Sistem Pendaftaran Tanah Adat di Bali. Acta Comitas: Jurnal Hukum Kenotariatan, 4(2). doi: https://doi.org/10.24843/AC.2019.v04.i02.p11.

Rachma, Y. (2019). Pelayanan Pendaftaran Tanah Sistematis Lengkap (PTSL) oleh Kantor Pertanahan Kabupaten Pangandaran di Desa Wonoharjo Kecamatan Pangandaran Kabupaten Pangandaran. Moderat: Iurnal Ilmiah Ilmu Pemerintahan, 5(4), 519-529. doi: http://dx.doi.org/10.25157/moderat.v5i4.3064.

\section{Makalah}

Sudantra, I Ketut, 2018. "Pensertifikatan Tanah Adat di Bali: mendiagnosa Implikasi Penunjukan Desa Pakraman Sebagai Subyek Hak Komunal Atas Tanah", Makalah disampaikan dalam Seminar Nasional Tanah Adat, Hukum Adat dan Organisasi Masyarakat Hukum Adat di Indonesia yang diselenggarakan oleh Program Studi Magister (S2) Kenotariatan Fakultas Hukum Universitas Udayana di Denpasar, 25 Juli 2018.

Wayan P. Windia, 2017. "Memahami Karakteristik Tanah Desa di Bali", Makalah Pokok-pokok pikiran yang disajikan sebagai pengantar dalam diskusi terfokus (FGD) yang diselenggarakan oleh Badan Pertanahan Nasional (BPN) Provinsi Bali, pada tanggal 30 Agustus 2017, bertempat di Gedung Nayaka Loka, Kebun Raya Bedugul.

\section{Peraturan Perundang Undangan}

Undang-Undang Dasar Negara Republik Indonesia Tahun 1945.

Undang-Undang Nomor 5 Tahun 1960 tentang Peraturan Dasar Pokok-Pokok Agraria (Lembaran Negara Republik Indonesia Tahun 1960 Nomor 104, Tambahan Lembaran Negara Nomor 2043).

Peraturan Menteri Agraria Tata Ruang/ Kepala Badan Pertanahan Nasional Republik Indonesia Nomor 12 Tahun 2017 Tentang Percepatan Pendaftaran Tanah 
Sistematis Lengkap (Berita Negara Republik Indonesia Tahun 2017 Nomor 1127).

Peraturan Menteri Agraria Tata Ruang/ Kepala Badan Pertanahan Nasional Republik Indonesia Nomor 6 Tahun 2018 Tentang Pendaftaran Tanah Sistematis Lengkap (Berita Negara Republik Indonesia Tahun 2018 Nomor 501).

Surat Keputusan Menteri Agraria Tata Ruang/Badan Pertanahan Nasional Nomor 276/KEP-19.2/X/2017 pada tanggal 23 Oktober 2017, yang menunjuk Desa Pakraman sebagai Subyek Hak Pemilikan Bersama Atas Tanah.

Peraturan Pemerintah Nomor 24 Tahun 1997 tentang Pendaftaran Tanah (Lembaran Negara Republik Indonesia Tahun 1997 Nomor 59, Tambahan Lembaran Negara Nomor 3696).

Peraturan Daerah Provinsi Bali Nomor 4 Tahun 2019 tentang Desa Adat di Bali (Lembaran Daerah Provinsi Bali Tahun 2019 Nomor 4 NoReg Peraturan Daerah Provinsi Bali : (4-131/2019), Tambahan Lembaran Daerah Provinsi Bali Nomor $4)$. 